\title{
Evaluation of Performance Employee (Study on Faculty of Educational Science Manado State University-Indonesia)
}

\author{
Roos M.S. Tuerah
}

Faculty Of Science Education Manado State University, Indonesia

\begin{abstract}
The main problem in this study related to Human Resources (HR) which is one of the main factors in improving the productivity of performance in the organization or agency. Therefore, it is necessary to have competent human resources that can support the improvement of performance achievement. The study aims to determine the performance of administrative staff at the science faculty of the Manado State University, Indonesia. By using a qualitative approach, respondents are taking data of all employees in the faculty of education, which amounted to 35 people. The conclusion shows that the performance of Employees in the faculty of education, Manado State University is influenced by the factors: Effectiveness and efficiency, Authority (authority), discipline, initiative. Performance appraisal of employees follows the applicable government regulations. It takes a sense of responsibility from all employees in carrying out their duties
\end{abstract}

Keywords: Employees, Performance evaluation

\section{Introduction}

Performance is a condition that must be known and confirmed to certain parties to determine the level of achievement of an agency is related to the vision of an organization and to know the positive and negative impact of an operational policy. Mink (1993) argues that high performing individuals possess some characteristics, such as: (a) achievement oriented, (b) having confidence, (c) control of self-administration staff, (d) competence.

Performance appraisals aim to assess how well they have done their jobs and what they must do to get better in the future. This is done by referring to the content of the work they do and what they expect to achieve every aspect of their work (Rivai et.al, 2011). The importance of human resource performance in creating high performing organizations, to support the implementation of the national discipline movement program and the provision of services to students.

Faculty of Science Education Manado State University need to uphold national discipline because the quality of human resources is one of the main factors to improve the productivity of an organization's performance or agency. Therefore, it is necessary human resources who have competence will be able to support the improvement of employee performance achievement on the faculty of education sciences.

During this time many government agencies have not had administrative staff with adequate competence, this is evidenced by the low productivity of administrative staff and the difficulty of measuring the performance of employees in the scope of government agencies (Nurmianto, Siswanto). This is in line with what the Minister of Administrative Reform and Bureaucracy Reform says, that only five percent of civil servants staff in Indonesia have competence in their fields. And his side as much as 95 percent of staff, according to his statement, has no special competence in his field alias only have general competence.

The work of the unit of work organizes the task of managing the administrative management program, and various tasks related to the main purpose and function. Up to now the performance assessment of civil servants uses a list of employee implementation assessments (DP3). The elements in DP3 consist of: loyalty, job performance, responsibility, obedience, honesty, cooperation, initiative and leadership.

List of employee implementation assessments is one-way, because it is done by the superior / authorized officer, if there is an objection from the assessed employee, the final decision of his judgment shall be 
returned to the appraiser officer. This creates an injustice in judgment. The elements assessed in DP3 generally only contain ideology and nationalism, while the performance appraisal itself is not illustrated. Therefore, a more complete new insrumen for personnel performance measurement is based on the function of the role of personnel (Government Regulation No.10/1999), as a requirement for payment of employee side benefits allowance, so it can not be a benchmark for assessment. For that which can be used as a temporary measure using the absence of morning and evening apples. When associated with the performance of individuals, that it shows the level of discipline that has been in accordance with the expected. The above conditions can have an impact on the lightness of the administrative staff workload.

Thus, competence shows the skills or knowledge characterized by propesionalism in a particular field as the most important, as the seed of the field. According to Spencer and Spencer (1993: 9), in Wibowo 2011, states that competence is the basic foundation of people's characteristics and indicates how to behave or think, equate situations and support for long periods of time. The factors are: commitment to the organization, desire achievement, cooperation, proactive, and discipline.

Based on the background of the above problems can be raised issues that can be I dentified is how to evaluate the performance of employees at the faculty of science education Manado State University, Indonesia.

Limiting the problem in this research are: Performance of employees at education faculty of Manado State University in Indonesia. The purpose of this research is as follows.

1. To evaluate the performance of civil servants on employees at the faculty of science education Manado State University, Indonesia

2. To find out what factors are the obstacles in the performance of employees on the faculty of science education Manado State University, Indonesia

\section{Literature Review \\ Performance Employee}

Etymologically, performance comes from the word performance. As stated by Mangkunegara (2005) that the term performance is derived from the word job performance or actual performance (achievement of work or actual achievement) achieved a person is the work in quality and quantity achieved by an employee in performing their duties in accordance with the responsibilities given to him. Furthermore Mangkunegara (2005), that in general the performance is divided into two, namely individual performance and organizational performance. Individual performance is the result of employee work both in terms of quality and quantity based on predetermined work standards, while organizational performance is a combination of individual performance with group performance. According Kewo (2017) the Internal control is a very important part in the overall spectrum control mechanisms are used to motivate, measure and impose sanctions on the actions of managers and employees of an organization. An effective control system is a prerequisite for better performance. According to Miah and Mia (1996) in Kewo, C.L (2017). Research on the relationship between internal control and managerial performance conducted by Miah and Mia (1996), which examines the internal control and performance manjerial on the organization of government agencies in New Zealand. Van Gramberg (2000) at the Victorian state government in Australia and Soobaroyen (2006) against the managers of companies in Australia.

Different from the education sector, in the government sector managerial performance According to Kewo (2014); managerial performance of local governments can be reflected in the financial statements of the local government. Performance is an overview of the level of achievement or implementation of activities/programs/policies in realizing the goals, objectives, mission and vision of the organization as stated in the formulation of strategic schemes (strategic planning) of an organization. It is generally described that performance is a feat which can be achieved by the organization in a given period.(Indra Bastian, 2006). Managerial performance is based on management functions which include planning, organizing, controlling and leadership. Performance measurement system can be used as a means of controlling the organization, because the measurement of performance is strengthened by establishing a reward and punishment system.

According Mangkunegara (2000), performance or work performance is the work of quality and quantity achieved by an employee in performing their duties in accordance with the responsibilities given to him. Meanwhile, according to Gibson et al. (1996) employee performance is a measure that can be used to determine the comparison of the results of execution of tasks, responsibilities provided by the organization 
at a certain period and can be relative to measure the performance of work or organizational performance. According to Rivai (2005), the word performance is a translation of the word performance that comes from the word to perform with some entries: 1 .to do or carry, executing; 2 . to discharge of fulfil; as vow; 3 . to execute or complete an understanding; 4 . to do what is expected of a person machine.

Organisational performance is a sign of the capacity of a company to efficiently achieve independent goals (Venkatraman \& Ramanujam, 1986). One of the elements that is assessable is the employees' performance through the level of their productivity. Several researches have been introducing various methods to evaluate organisational performance (Wong \& Wong, 2007; Prajogo, 2007). This includes the quality, quantity, knowledge or creativity of individual towards the accomplished works that are in accordance with the responsibility during a specified period- in other words, the assessment systems must have some standard parameters that can be relied upon

According to Swart et al., (2005), bridging the performance gap refers to implementing a relevant training intervention for the sake of developing particular skills and abilities of the workers and enhancing employee performance. He further elaborate the concept by stating that training facilitate organization to recognize that its workers are not performing well and a thus their knowledge, skills and attitudes needs to be moulded according to the firm needs. There might be various reasons for poor performance of the employees such as workers may not feel motivated anymore to use their competencies, or may be not confident enough on their capabilities, or they may be facing work- life conflict. All the above aspects must be considered by the firm while selecting most appropriate training intervention, that helps organization to solve all problems and enhance employee motivational level to participate and meet firm expectations by showing desired performance. As mentioned by Swart et al.(2005) this employee superior performance occur only because of good quality training program that leads to employee motivation and their needs fulfilment. According to Wright and Geroy (2001), employee competencies changes through effective training programs. It not only improves the overall performance of the employees to effectively perform the current job but also enhance the knowledge, skills an attitude of the workers necessary for the future job, thus contributing to superior organizational performance. Through training the employee competencies are developed and enable them to implement the job related work efficiently, and achieve firm objectives in a competitive manner.

According to Prawirosentono (1999), performance is the result of work that can be achieved by a person or group of people within an organization, in accordance with their respective authority and responsibility, in an effort to achieve the relevant legal objectives, not violating law and in accordance with moral or ethics. High performance can be realized, if managed properly. That is why every organization needs to apply performance management. Regarding this performance, people often make the mistake of thinking that evaluating performance is performance management. Though evaluating performance or providing an assessment of performance is only a part of the performance management system. For according to Bacal (2005), performance management is a continuous, ongoing process of communication, carried out in partnership between an employee and his / her direct supervisor. This process includes building clear expectations and understanding of the work to be done.

Thus performance management is a system that has a number of parts, all of which must be included, if they expect or want this performance management system to provide added value to organizations, managers and employees. Ventrakaman and Ramanujam (1986) describes performance as a reflection of the achievement of corporate success that can be made as a result that has been achieved from various activities undertaken. Another opinion put forward by Waterhouse and Svedsen (1998) that defines performance as measurable actions or activities. Furthermore, performance is a reflection of the achievement of quantity and quality of work produced by individuals, groups, or organizations and can be measured. The same opinion is also put forward by Wells and Spinks (1996) that performance shows behavioral results that are of value with the criteria or quality standards. Mathis and Jackson (2006), define that performance is essentially what employees do and do not do.

Employee performance is what affects how much they contribute to the organization that includes (1) output quantities, (2) output quality, (3) output period, (4) attendance at work, (5) cooperative attitude. Health services is a company that provides services that are service. To produce a quality service, then things about consumers need to be noticed, both internal consumers and external consumers. Especially in the problem of providing quality services that need to be considered is the internal customers, because they are the people who are influential in the performance of the company and is the person who is in the 
company. To maintain and improve the quality of services, this is highly dependent on the performance of the task force (Nasution, 2001)

Gilbert (1977) performance is what can be done according to task and function. Notoatmojo (1992) performance is dependent on ability, capacity, help, incentive, environment, validity and evaluation. The major dictionary of Indonesia, performance comes from the English language performance which means the efficiency, achievement, success in carrying out the tasks that are the responsibility. Based on the above theories can be concluded that the performance is the result of work that can be achieved by employees within an organization, in accordance with the authority and responsibility provided by the organization in an effort to achieve the vision, mission and objectives of the organization concerned legally, not violating the law and in accordance with the moral as well ethics.

Performance is the appearance of the work of personnel both quantity and quality within an organization. Appearance of work is not limited to personnel who hold functional or structural positions, but also on the whole range of personnel within the organization. A description of performance appraisal involves three important components: goal, size and peniaian. Determining the objectives of each organizational unit is a strategy to improve performance. This objective will provide direction and influence how the organization's expected performance behavior towards each personnel. Goal setting is not enough, therefore it is necessary to measure whether a personnel has achieved a predetermined performance. The quantitative and qualitative measures of performance standards for each task and position of personnel play an important role

Regular assessment is associated with the process of achieving the performance goals of each personnel. This action will make the personnel to always orientate towards the goals and behave accordingly and direction with the aim to be achieved. Thus it is clear that the notion of performance appraisal with objective description, operational size and regular assessment has an important role in maintaining and improving the motivation of personnel, among others:

- Performance assessment

- Assessment based behavior

- Values are based on critical incidents

- Assessment based on effectiveness

- Rating by rank

\section{Factors Affecting Performance}

According to Atmosoeprapto (2001), performance is the ratio between complaints (ouput) achieved with the input (input) provided. In addition, performance is also a result of efficiency of input management and the effectiveness of target achievement. Therefore, the effectiveness and efficiency of high work will result in high performance as well. To achieve a high performance requires a mental attitude that has a view far ahead. One must have an optimistic attitude, that the quality of life and life of tomorrow is better than today

Another opinion expressed by Furtwengler (2002) which suggests that to improve employee performance, the organization needs to make performance improvements. The performance improvement that should be considered by the organization is the factor of speed, quality, service, and value. In addition to these four factors, there are also other factors that influence the performance of employees, namely interpersonal skills, mental to succeed, open to change, creativity, communication skills, initiative, and ability to plan and organize activities that became. Factor factor is not directly related to the work, but has the same weight of influence.

Hinggins in Umar (2005) identifies several variables that are closely related to performance, ie job quality, employee honesty, initiative, attendance, attitude, cooperation, reliability, knowledge of work, responsibility and time utilization. Gibson (1996) states that there are three groups of variables that affect performance and behavior: (1) individual variables, including ability and skill, physical and mental, background, experience and demography, age and gender, origin and so on. Abilities and skills are the main factors affecting individual performance, whereas demographics have an indirect relationship to behavior and performance, (2) organizational variables, ie resources, leadership, rewards, structure and job design, (3) psychological variables, perceptions, attitude, personality, learning, job satisfaction and motivation. Perceptions, attitudes, personality and learning are complex and difficult to quantify and the opportunities for understanding are difficult to achieve, because an individual enters and joins a work organization at 
different ages, ethnicities, backgrounds, cultures and skills. The description of the performance variables can be seen as follows: 1. Responsibility, 2. Initiative, 3. Number of jobs

\section{Research Methods}

In this study, researchers chose to use a qualitative approach. Cresweel (1998: 15) defines qualitative research as follows: "Qualitative research is an inquiry process of understanding based on distinct methodological traditions of inquiry that explorer a social or human problem. The researcher builds a complex, holistic picture, analyzes worlds, reports detailed views of informants, and conducts the study in a natural setting"

Qualitative research is a method of exploring and understanding the meanings by which some individuals or groups of people are perceived as derived from social or humanitarian problems. This qualitative process of research involves important efforts, such as asking questions and procedures, collecting specific data from participants, analyzing data inductively from specific themes to common themes, and interpreting the meaning of the data.

This research was conducted at Faculty of Education Manado State University in Indonesia.According Sugiono (2008: 224), data collection techniques is the most stragegis step in the study, because the main purpose of research is to get data. Without knowing the techniques of data collection, the researchers will not get data that meets the established data standards. In this regard, the data collection techniques that will be used by researchers in this study are: Observation, Interview, Documentation, and literature study

Data analysis techniques used in this study consisted of four activities that occur simultaneously, namely data reduction, data presentation, and withdrawal of conclusions. The following is the relationship between the components of data analysis

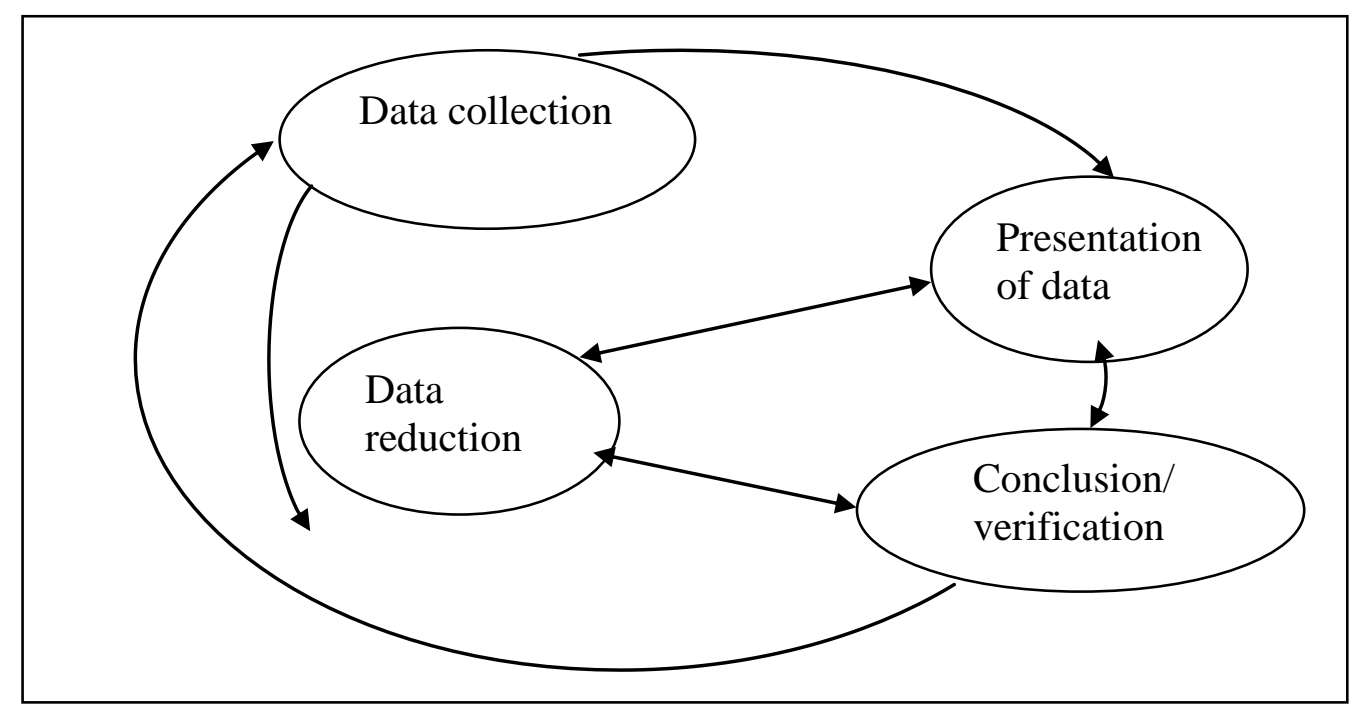

Figure Components of Data Analysis.

Source: Sugiyono (2008: 276), Miles and Huberman (1999: 20)

\section{Result and Discussion}

1. Factors Affecting Employee Performance on the faculty of education Manado state University. Based on the results of observations and interviews with employees in fakculty of education manado state university, can be described that there are several factors that affect employee performance:

a. Effectiveness and efficiency

When a particular goal is finally achieved, we may say that the activity is effective but if the consequences of the activity are not sought to judge the importance of the results achieved so as to result in satisfaction even though effectively called inefficient. Conversely, if the consequences are sought is not important or trivial then the activity is efficient (Prawirosentono, 1999: 27).

The results of observations and interviews with employees indicate that the effectiveness and efficiency factors manifest in their work every day. Every day the employees are required to follow the morning apple at 07.30 and after getting a briefing then they do attendance with finger print as a proof of 
presence. Finger print is also will be used as a calculation for the payment of food money and transport employees. In addition, the recap of attendance through the finger print will determine how much performance allowances will be obtained by employees.

Therefore, the employee at the Faculty of Education Unima always work effectively and efficiently by supporting the vision and mission of FIP Unima. According to Atmosoeprapto (2001), performance is the ratio between complaints (ouput) achieved with the input (input) provided. In addition, performance is also a result of efficiency of input management and the effectiveness of target achievement. Therefore, the effectiveness and efficiency of high work will result in high performance as well. To achieve a high performance requires a mental attitude that has a view far ahead. One must have an optimistic attitude, that the quality of life and life of tomorrow is better than today

b. Authority

Authority according to is the nature of a communication or command in a formal organization owned by an organization member to another member to perform a work activity in accordance with its contribution (Prawirosentono, 1999: 27). The order says what is allowed and what should not be in the organization. Based on the statute of Manado State University, then that holds the authority for employees in the environment faculty of science education Manado state university circle is the Dean, Head and Sub-Heads in each field. Direct supervisors have the authority to control employees in carrying out their jobs every day.

c. Discipline

Discipline is obedient to the laws and regulations that apply (Prawirosentono, 1999: 27). Thus, employee discipline is the activity of the employee concerned in respecting the employment agreement with the organization in which he works. At Manado State University, including environment faculty of science education Manado state university, discipline is one of the important indicators in determining the assessment of employee performance.

d. Initiative

The initiative is related to the power of thought and creativity in shaping the idea to plan something related to organizational goals. According Mangkunegara (2000), performance or work performance is the work of quality and quantity achieved by an employee in performing their duties in accordance with the responsibilities given to him. Meanwhile, according to Gibson et al. (1996) employee performance is a measure that can be used to determine the comparison of the results of execution of tasks, responsibilities provided by the organization at a certain period and can be relative to measure the performance of work or organizational performance.

2. Performance Indicators faculty of science education Manado state university employee

Indicators to measure the performance of employees / employees individually there are six indicators, namely (Robbins, 2006: 260):

1. Quality. The quality of work is measured by employee perceptions of the quality of work produced and the perfection of tasks to the skills and abilities of employees.

2. Quantity. The resulting amount is expressed in terms such as number of units, number of completed activity cycles.

3. Timeliness. It is the activity level completed at the beginning of the stated time, viewed from the point of coordination with the output and maximizing the time available for other activities.

4. Effectiveness. It is the level of use of organizational resources (energy, money, technology, raw materials) maximized with the intention of increasing the yield of each unit in the use of resources.

5. Independence. It is the level of an employee who will be able to perform his work function Work commitment. Is a level where employees have a working commitment with the agency and the responsibility of employees to the office.

\section{Conclusion and Recomendation}

Conclusion

1. The performance of the faculty of education faculty of Manado State University is influenced by the factors: Effectiveness and efficiency, Authority, discipline, initiative.

2. Assessment of work performance of faculty of science faculty of Manado State University have followed the prevailing government regulation.

Suggestion

1. It takes a sense of responsibility from all employees in performing their duties. 
2. Need further research on the factors that affect the performance of civil servants / state apparatus by including other factors that have not been studied.

\section{References}

[1] A.A. Anwar Prabu Mangkunegara. Manajemen Sumber Daya Manusia. Penerbit PT. Remaja Rosdakarya, Bandung 2000.

[2] Davis, keith., 2002. Fundamental organization behavior, diterjemahkan agus dharma,

[3] Jakarta: erlangga

[4] Dessler, gary., 1992, Manajemen Sumber Daya Manusia, Jakarta: prenhallindo

[5] Elnaga, A., \& Imran, A. (2013). The effect of training on employee performance. European Journal of Business and Management, 5(4), 137-147.

[6] Indra Bastian.(2006).Planning and Budgeting System of Local Government in Indonesia, Salemba Empat, Jakarta

[7] Kewo, C. L. (2017). The influence of internal control implementation and managerial performance on financial accountability local government in Indonesia. International Journal of Economics and Financial Issues, 7(1), 293-297.

[8] ----------, 2014. The Effect of Participative Budgeting, Budget Goal Clarity and Internal Control Implementation on Managerial Performance. Research Journal of Finance and Accounting, 5(12), pp.81-87.

[9] Miah, N.Z., Mia, L. (1996), Decentralization, accounting controls and performance of government organization: A New Zaeland empirical study. Financial Accoutability and Management Journal, 12(1), 173-189.

[10] Prawirosentono, Suryadi. 1999. Kebijakan Kinerja Karyawan. Yogyakarta: BPFE.

[11] Prajogo, D. I. (2007). The relationship between competitive strategies and product quality. Industrial Management and Data Systems, 107(1), 69-83. http://dx.doi.org/10.1108/02635570710719061

[12] Stoner James, 1992. Management. Terjemahan: A. Maulana, Hendardi, Kristina. Jakarta: Penerbit Erlangga

[13] Soobaroyen, T. (2006), Management control system and dysfunctional behavior. An Empirical Investigation, School of Management and Business. United Kingdom: Univesity of Wales.

[14] Swart, J., Mann, C., Brown, S. and Price, A. (2005),Human Resource Development: Strategy and Tactics, Elsevier Butterworth-Heinemann Publications, Oxford.

[15] Umam Khaerul, 2010. Perilaku Organisasi. Bandung: Pustaka Setia.

[16] -----------. Perencanaan dan Pengembangan Sumber Daya Manusia. Penerbit Refika.

[17] Van Gramberg, B. (2000), Managerialism in local goverment-victoria, Australia. The International Journal of Public Sector Management, 13(5), 476-492.

[18] Venkatraman, N., \& Ramanujam, V. (1986). Measurement of business economic performance: an examination of method convergence. Journal of management Development, 13(1), 109-22.

[19] Wong, W. P., \& Wong, K. Y. (2007). Supply chain performance measurement system using DEA modeling. Industrial Management and Data Systems, 107(3), 361-81. http://dx.doi.org/10.1108/02635570710734271

[20] Wright, P. and Geroy, D.G. (2001), "Changing the mindset: the training myth and the need for wordclass performance", International Journal of Human Resource Management, Vol. 12 No. 4, pp. 586600 . 